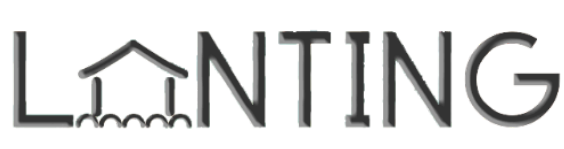

\title{
PUSAT PELAYANAN AUTIS DI BANJARBARU
}

\author{
Alya Anisah Savitry Agoes \\ Program Studi Teknik Arsitektur Fakultas Teknik Universitas Lambung Mangkurat \\ alyaagoes@gmail.com
}

\section{Ira Mentayani}

Program Studi Teknik Arsitektur Fakultas Teknik Universitas Lambung Mangkurat ira arch@ulm.ac.id

\begin{abstract}
ABSTRAK
Autisme bukanlah sebuah penyakit, melainkan merupakan gangguan atau kelainan spektrum pada otak yang mengakibatkan para penyandang autis tidak dapat disembuhkan secara total. Hal terbaik yang dapat dilakukan adalah dengan memberikan perawatan yang tepat untuk membantu penyandang autis menyesuaikan diri dengan kondisinya, baik secara terapik maupun edukatif. Fasilitas yang memadai sangat dibutuhkan untuk mengembangkan dan menggali potensi yang ada pada setiap penyandang autis. Fasilitas pelayanan yang tersedia saat ini masih belum cukup baik ditinjau dari segi keamanan maupun kenyamanan, dan belum mampu memenuhi kebutuhan para penyandang autis untuk mendukung kegiatan pengembangan diri mereka. Sehingga dirasa perlu adanya Pusat Pelayanan khusus untuk para penyandang autis yang mampu menjadi sarana terapi dan pembelajaran yang baik dan tepat untuk penyandang autis mengembangkan kemampuan diri mereka. Hal tersebut diwujudkan dengan menggunakan metode Human Centered Design (HCD) dan konsep penerapan prinsip The Autism ASPECTSS Design Index untuk menciptakan Pusat Pelayanan Autis yang baik dan tepat, serta sesuai dengan karakteristik dan kebutuhan para penyandang autis.

Kata kunci: Autisme, Pusat Pelayanan Autis, Human Centered Design, The Autism ASPECTSS Design Index.
\end{abstract}

\section{ABSTRACT}

Autism is not a disease, but rather a spectrum disorder in the brain that causes autistic people cannot be completely cured. The best thing that can be done is to provide appropriate care to help people with autism adjust to their conditions, both therapeutically and educatively. Adequate facilities are urgently needed to develop and explore the potential that exists in every autistic person. The service facilities available at this time are still not good enough in terms of safety and comfort, and have not been able to meet the needs of people with autism to support their personal development activities. So that it is felt necessary to have a special Care Center for people with autism who are able to be a good and appropriate means of therapy and learning for people with autism to develop their abilities. This was realized by using the Human Centered Design (HCD) method and the concept of applying the principles of The Autism ASPECTSS Design Index to create a good and appropriate Autism Care Center, and in accordance with the characteristics and needs of people with autism.

Keywords: Autism, Autism Care Center, Human Centered Design, The Autism ASPECTSS Design Index. 


\section{PENDAHULUAN}

Autisme merupakan bagian dari Autism Spectrum Disorder (ASD). Autisme bukanlah gangguan kejiwaan, melainkan gangguan perkembangan pada otak yang membuat otak tidak berfungsi selayaknya otak normal. Yuwono (2009:26) menuliskan bahwa autis adalah suatu gangguan perkembangan neurobiologis yang sangat kompleks dalam kehidupan sehari-hari, gangguan-gangguan ini meliputi gangguan dalam kemampuan berinteraksi sosial, gangguan dalam kemampuan berkomunikasi, gangguan dalam berbahasa dan berperilaku, serta gangguan terhadap emosi, dan gangguan terhadap kepekaan sensori, bahkan pada beberapa kasus juga terdapat gangguan pada motorik.

Berdasarkan data yang dirilis World Health Organization (WHO), prevalensi penyandang autisme di Indonesia meningkat sangat pesat, dari $1 / 1.000$ penduduk menjadi $8 / 1.000$ penduduk yang mana telah melampaui rata-rata dunia yaitu $6 / 1.000$ penduduk. Menurut data Badan Pusat Statistik dan mengacu pada penelitian yang dilakukan oleh Kementerian Pemberdayaan Perempuan dan Perlindungan Anak dengan Konsultan Smart Applied Behaviour Analysis, jumlah autisme di Indonesia diperkirakan mengalami peningkatan sekitar 500 orang setiap tahunnya.

Di Kalimantan Selatan, jumlah kasus anak berkebutuhan khusus (ABK) ternyata juga masih terbilang cukup tinggi. Dari sekian jenis keterbelakangan tumbuhkembang ini, paling dominan adalah kasus autisme. Menurut perhitungan Ketua Perhimpunan Fisioterapi Anak Indonesia (FPAl) Kalimantan Selatan, jumlah anak penyandang autisme yang cukup tinggi berada di wilayah Kota Banjarbaru. Pada Januari 2018 kemarin, jumlahnya terdata mencapai 500 kasus, dimana artinya ada kemungkinan penambahan jumlah di tahun 2020 ini.

Autisme bukanlah sebuah penyakit, melainkan merupakan gangguan atau kelainan spektrum pada otak yang mengakibatkan para penyandang autisme tidak dapat disembuhkan secara total. Hal terbaik yang dapat dilakukan adalah dengan memberikan perawatan yang tepat untuk membantu penyandang autism menyesuaikan diri dengan kondisinya, baik secara terapik 2 maupun edukatif. Yatim (2011) dalam Kurnia dkk (2014) membuktikan bahwa sebanyak $10 \%$ penyandang autis yang mendapatkan bimbingan dan perawatan yang baik dan tepat, telah berhasil melakukan hubungan sosial dan perilakunya sudah mendekati normal. Saat ini sudah tersedia banyak sekali metode terapi untuk para penyandang autis yang sudah terbukti mampu membuat para penyandang autis tersebut hidup lebih baik dan lebih mandiri, serta lebih siap untuk terjun dan berinteraksi langsung ke masyarakat.

Selain dengan memberikan berbagai macam jenis terapi medis yang ada, para penyandang autis juga berhak mengembangkan diri mereka melalui pendidikan seperti anak-anak normal lainnya. Pendidikan merupakan hal yang penting untuk diberikan sejak usia dini. Setiap anak, termasuk anak berkebutuhan khusus, memiliki hak yang sama untuk mendapatkan pendidikan. Bedanya hanya pada tingkat pelayanan pendidikan yang sesuai dengan kebutuhan masing masing anak.

Sekolah Luar Biasa (SLB) dan sekolah inklusi saat ini menjadi satu-satunya pilihan terbaik bagi orangtua anak penyandang autisme untuk menyekolahkan anak mereka. Menurut survey yang dilakukan penulis, di Banjarbaru baru terdapat 1 sekolah inklusi (sekolah gabungan) yang juga menyediakan sarana terapi kepada anak berkebutuhan khusus. Sekolah inklusi ini didirikan oleh Yayasan Al-Madani yang bekerja sama dengan komunitas Bina Autis Indonesia, yang berada di Jl. Guntung Manggis, RT. 18 RW. 3, Landasan Ulin, Kota Banjarbaru. Saat ini, Anak Berkebutuhan Khusus yang mengikuti bimbingan di Al-Madani tercatat ada 23 orang anak. 


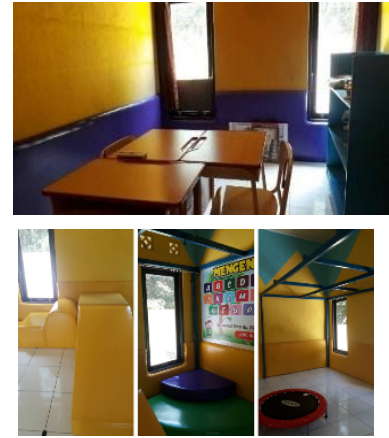

Gambar 1. Yayasan Al-Madani

Sumber: Dokumentasi Pribadi (2020)

Fasilitas pelayanan untuk para penyandang autis yang tersedia saat ini belum mampu menjadi ruang yang baik dan tepat untuk para penyandang autis mengembangkan diri. Fasilitas yang memadai sangat dibutuhkan untuk mengembangkan dan menggali potensi yang ada pada setiap penyandang autis, sehingga dirasa perlu adanya Pusat Pelayanan khusus untuk para penyandang autis di Banjarbaru yang mampu menjadi sarana terapi dan pembelajaran yang baik dan tepat untuk anak-anak autis mengembangkan kemampuan diri mereka.

\section{PERMASALAHAN}

Mengacu pada beberapa hal yang melatarbelakangi dirancangnya Pusat Pelayanan Autis di Banjarbaru ini serta faktor-faktor yang mempengaruhinya, maka rumusan permasalahan yang diangkat adalah: bagaimana rancangan Pusat Pelayanan Autis di Banjarbaru yang mampu menciptakan ruang yang baik dan tepat untuk mendukung kegiatan pengembangan diri para penyandang autis?

\section{TINJAUAN PUSTAKA}

\section{A. Tinjauan Autisme}

1. Definisi Autis

Manusia dilahirkan dalam keadaan yang berbeda-beda dan memiliki keunikannya masing masing. Beberapa diantara manusia, ada yang terlahir dengan kondisi khusus. Salah satu kekhususan yang ada pada manusia tersebut adalah autisme atau yang biasa dikenal dengan Autism
Spectrum Disorder (ASD). Leo Kanner adalah tokoh yang sering disebut sebagai peneliti pertama yang meneliti dan menemukan gangguan autisme. Kanner mempublikasikan makalah pertamanya mengenai penelitiannya terhadap autism ini di Amerika pada tahun 1943. Kanner memakai istilah 'autistic' untuk mendefinisikan seseorang yang secara sosial tidak memiliki keinginan untuk bergaul dan tenggelam dengan rutinitasnya sendiri, seseorang yang harus berusaha keras untuk dapat menguasai bahasa, namun tak jarang memiliki kemampuan intelektual yang tinggi.

Menurut Jepson (2008:1), Autism

Spectrum Disorder (ASD) adalah sekelompok penyakit yang ditandai dengan keterlambatan perkembangan bahasa, gangguan interaksi sosial, dan pola perilaku restriktif dan stereotip.

\section{Klasifikasi Autis}

American Psychiatric Association dalam Diagnostic and Statistical Manual of Mental Disorders Fifth Edition DSM-V (2013) membagi autism menjadi dua jenis ditinjau dari kemampuan stimulasi sensorisnya yaitu hypersensitive dan hyposensitive. Jenis hipersensitif adalah penyandang autis yang memiliki tingkat sensitivitas berlebih terhadap stimulasi sensori, contohnya merasa terganggu dengan suara kipas angin yang berputar, merasa pusing saat melihat warna yang terlalu terang, sedangkan jenis hiposensitif adalah penyandang autis yang memiliki kepekaan rendah terhadap lingkungan sekitar.

Beberapa contoh gejala dari klasifikasi hipersensitif adalah:

- Respon ekstrim atau berlebihan terhadap suara tertentu yang biasanya tidak memberikan efek tertentu kepada orang lain.

- Mudah terdistraksi terhadap suara yang biasanya tidak terdengar oleh orang lain.

- Menghindari kontak fisik dan keramaian. 
- Memiliki keseimbangan yang kurang baik.

Beberapa contoh gejala dari klasifikasi hiposensitif adalah:

- Memiliki toleransi yang tidak biasa terhadap rasa sakit.

- Kesulitan mengontrol gerakan atau kekuatan.

- Tidak bisa duduk diam.

- Cenderung membahayakan diri sendiri.

\section{Jenis Terapi}

1.) Terapi Applied Behaviorial Analysis (ABA)

Terapi ABA atau yang biasanya dikenal dengan terapi perilaku, adalah sebuah metode terapi yang berupaya untuk merubah perilaku pada anak autis dalam arti pengurangan perilaku yang berlebihan dan penambahan perilaku yang berkekurangan. Tujuan penanganan ini terutama adalah untuk meningkatkan pemahaman dan kepatuhan anak terhadap aturan. Terapi ini umumnya mendapatkan hasil yang signifikan bila dilakukan secara intensif, teratur dan konsisten pada usia dini.

\section{2.) Terapi Wicara}

Terapi wicara adalah metode terapi yang digunakan untuk menangani penyandang autis dengan gangguan kemampuan berbicara dan berkomunikasi. Pada dasarnya, terapi ini dilakukan untuk merangsang anak agar berbicara. Metode yang digunakan dapat berupa dengan mengajak anak untuk berkomunikasi, atau dengan mengajaknya bermain.

\section{3.) Terapi Okupasi}

Kusnanto (2002) dalam Desiningrum (2016) mendefinisikan terapi okupasi sebagai suatu usaha penyembuhan anak yang mengalami kelainan mental dan fisik dengan cara memberikan keaktifan kerja, keaktifan kerja itulah yang akan mengurangi penderitaan yang alami. Metode pemulihan yang digunakan adalah dengan cara membuat persendian, otot, dan kondisi tubuh dapat berfungsi sebagaimana mestinya dan dapat memenuhi kebutuhan hidup.

\section{4.) Terapi Sensori Integrasi}

Terapi ini diberikan sesuai dengan kebutuhan anak. Dalam terapi diusahakan anak memberi reaksi yang baik terhadap rangsangan. Saat terapi, anak diharapkan berperan aktif agar muncul perubahan positif. Biasanya terapis akan mengarahkan kegiatan yang dapat memberikan tantangan secara bertahap. Teori sensori integrasi hanya sebagian dari pendekatan terapi okupasi.

\section{5.) Terapi Aktivitas}

Terapi aktivitas adalah terapi yang bertujuan untuk membantu para penyandang autis untuk melakukan aktivitas dan tugas sehari-hari menjadi lebih baik. Aktivitas sehari-hari tersebut contohnya berupa memegang peralatan makan dengan benar, memakai pakaian dengan benar, dan lain-lain.

\section{6.) Terapi Bermain}

Ruang lingkup terapi bermain anak autis dirumuskan berdasarkan karakteristik anak, tujuan maupun sasarannya, yaitu:

- Bermain yang berkaitan dengan latihan sensorik motorik; latihan pengembangan fungsi mata, telinga, dan latihan otot, seperti dokter-dokteran, bermain plastisin.

- Bermain untuk mengembangkan imajinasi, kreasi, ekspresi, memupuk kekuatan otot, melatih memecahkan masalah, dan menimbulkan rasa percaya diri, seperti latihan memasang-bongkar puzzle, mewarnai gambar.

\section{B. Tinjauan Arsitektural}

\section{Tinjauan Elemen Pembentuk Suasana pada Ruang}

Rasmussen (1964) dalam bukunya yang berjudul Experiencing Architecture mengemukakan bahwa arsitektur bukan 
hanya sesuatu yang terlihat dan dapat diraba, akan tetapi juga sesuatu yang dapat didengar dan dirasakan. Rasmussen juga berpendapat bahwa sebuah karya arsitektur tidak cukup untuk dilihat saja, tetapi juga harus dialami dan dirasakan.

Menurut Rasmussen, terdapat tiga aspek yang biasanya digunakan untuk membentuk suasana ruang kepada para penggunanya. Ketiga aspek tersebut adalah:

\section{1.) Tekstur}

Tekstur menjadi salah satu alat untuk memberikan pengalaman dan memunculkan suasana ruang karena tekstur adalah sesuatu yang dapat dirasakan langsung dengan indera peraba. Penggunaan material yang beragam juga dapat memberikan sensasi rasa tekstur yang berbeda-beda, sehingga suasana yang akan didapatkan pun juga menjadi berbeda-beda.

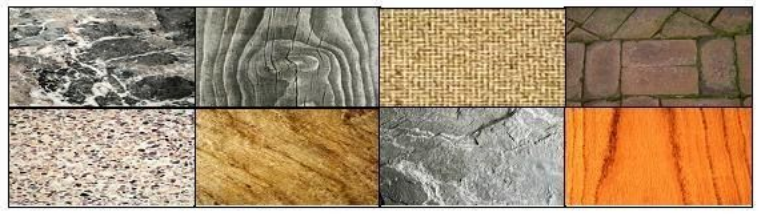

Gambar 2. Macam-macam Tekstur Sumber:

https://wisnujadmika.wordpress.com/tag/unsur-uns ur-seni-rupa/ (2020)

\section{2.) Cahaya}

Rasmussen menjadikan cahaya sebagai poin penting dalam arsitektur karena menurutnya kebanyakan arsitek melihat cahaya hanya dari segi kuantitasnya dan bukan dari segi kualitasnya. Pendapat Rasmussen mengenai cahaya adalah bahwa cahaya dapat memunculkan aura ke sesuatu yang dicapainya.

\section{3.) Warna}

Warna adalah aspek ketiga yang juga tak kalah penting untuk menciptakan suasana ruang. Rasmussen mengatakan bahwa dalam arsitektur, warna digunakan sebagai penekanan karakter bangunan, selain itu juga untuk menonjolkan bentuk dan bahan dari bangunan tersebut serta untuk menjelaskan bagian-bagiannya.

\section{1.) Persegi/Kotak}

\section{Tinjauan Bentuk}

Kotak menunjukkan kejujuran dan stabilitas. Kotak adalah bentuk yang umum digunakan dan terpercaya. Bentuk kotak melambangkan kedamaian dan keselarasan. Dalam pemanfaatan ruang, bentuk kotak dianggap menjadi bentuk yang paling efisien dan fungsional. Bentuk kotak pada umumnya tidak menarik perhatian, namun dapat ditambahkan sedikit twist agar menjadi lebih menarik.
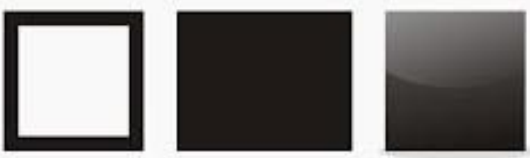

Gambar 3. Bentuk Persegi

Sumber: http://celotehcelatah.blogspot.com/ (2020)

\section{2.) Lingkaran}

Bentuk lingkaran melambangkan pergerakan yang bebas. Dari segi psikologis, lingkaran dapat memunculkan rasa ketenangan, rasa hangat, dan cinta. Ruang berbentuk lingkaran dianggap ramah anak karena tidak memiliki sudut tajam dan fleksibel. Bentuk lingkaran dapat digunakan untuk menarik perhatian.

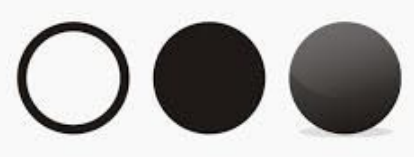

Gambar 4. Bentuk Lingkaran Sumber: http://celotehcelatah.blogspot.com/ (2020) 


\section{Tinjauan Psikologi Warna}

Menurut Astuti (2018) penyandang autis dapat diterapi dengan menggunakan metode terapi warna untuk meningkatkan kesadaran mereka terhadap lingkungan sekitarnya. Astuti (2018) mengemukakan psikologi warna yang baik diaplikasikan pada penyandang autis sebagai berikut:

Tabel 1. Psikologi Warna untuk Penyandang Autis

\begin{tabular}{|l|l|l|}
\hline Nama & Warna & \multicolumn{1}{|c|}{ Definisi } \\
\hline Merah & $\begin{array}{l}\text { Warna merah } \\
\text { memiliki karakter } \\
\text { kuat dan antusias. } \\
\text { Warna merah sangat } \\
\text { baik untuk mengasah } \\
\text { sensoris penyandang } \\
\text { autis, terutama } \\
\text { kategori hiposensitif. } \\
\text { Penerapan warna } \\
\text { merah pada dinding } \\
\text { interior perlu } \\
\text { diperhatikan dan } \\
\text { disarankan untuk } \\
\text { tidak diterapkan } \\
\text { sepenuhnya karena } \\
\text { dapat mengganggu. }\end{array}$ \\
\hline Putih & $\begin{array}{l}\text { Warna kuning } \\
\text { memiliki karakter } \\
\text { hangat. Kuning juga } \\
\text { menimbulkan kesan } \\
\text { kekayaan dan } \\
\text { kebahagiaan. Warna } \\
\text { kuning bagus untuk } \\
\text { meningkatkan } \\
\text { konsentrasi sehingga } \\
\text { cocok diterapkan } \\
\text { pada ruang belajar } \\
\text { maupun ruang kerja. }\end{array}$ \\
\hline & $\begin{array}{l}\text { Warna putih dapat } \\
\text { memberikan kesan } \\
\text { suasana cerah dan } \\
\text { luas sehingga cocok } \\
\text { untuk diterapkan di } \\
\text { ruang yang sempit } \\
\text { dan kurang }\end{array}$ \\
\hline
\end{tabular}

\begin{tabular}{|c|c|}
\hline & $\begin{array}{lr}\text { pencahayaan. } & \text { Putih } \\
\text { juga } & \text { merupakan } \\
\text { warna } & \text { netral } \\
\text { sehingga } & \text { mudah } \\
\text { untuk menambahkan } \\
\text { aksen } & \text { gabungan } \\
\text { dengan } & \text { warna } \\
\text { lainnya. } & \end{array}$ \\
\hline Biru & $\begin{array}{l}\text { Warna biru } \\
\text { melambangkan } \\
\text { kedamaian, } \\
\text { keakraban, dan } \\
\text { tenang. Warna biru } \\
\text { dianggap sebagai } \\
\text { spektrum warna } \\
\text { yang paling mudah } \\
\text { direspon oleh para } \\
\text { penyandang autis. } \\
\text { Warna biru dijadikan } \\
\text { sebagai simbolisasi } \\
\text { warna pada } \\
\text { kampanye paran } \\
\text { \#LightltUpBlue yang } \\
\text { dilaksanakan setiap } \\
\text { tanggal 2 April untuk } \\
\text { memperingati Hari } \\
\text { Autis Sedunia. }\end{array}$ \\
\hline
\end{tabular}

(Sumber: AD Astuti, 2018)

\section{Tinjauan Konsep}

1. Tinjauan Metode Human Centered Design (HCD)

Pencapaian tujuan dan penyelesaian permasalahan dari perancangan Pusat Pelayanan Autis di Banjarbaru ini diselesaikan dengan menggunakan metode Human Centered Design. Metode Human Centered Design (HCD) adalah suatu metode perancangan yang berfokus kepada penggunanya (ISO 9241, 2018). Dalam metode human centered design, perancang diharuskan untuk menghasilkan suatu solusi rancangan yang menyesuaikan dengan kebutuhan, kebiasaan perilaku, emosional, dan kapabilitas penggunanya. Metode ini juga bertujuan untuk memberikan kehidupan yang lebih baik bagi penggunanya, sehingga metode ini dianggap menjadi metode yang paling tepat untuk digunakan dalam 
penyelesaian permasalahan Pusat Layanan Autis di Banjarbaru.

Pada metode human centered design, terdapat tiga fase yang harus dilakukan sebelum menghasilkan suatu rancangan, yaitu inspiration, ideatation, dan implementation phase.

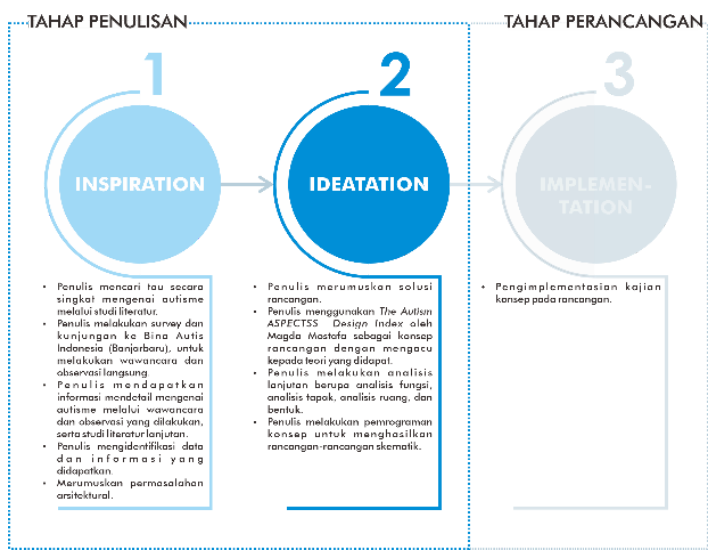

Gambar 5. Tahapan Metode HCD Sumber: Analisis Pribadi (2020)

2. Tinjauan Prinsip The Autism ASPECTSS Design Index

Perancangan Pusat Pelayanan Autis di Banjarbaru ini menggunakan konsep 'The Autism ASPECTSS Design Index' oleh Magda Mostafa sebagai parameter desain untuk menciptakan ruang yang baik dan tepat untuk mendukung kegiatan pengembangan diri para penyandang autis.

\section{1.) Acoustics}

Pada aspek akustik ini, dibutuhkan pengurangan sumber kebisingan internal dan eksternal melalui berbagai cara seperti dinding rongga, kedap suara, dan konfigurasi spasial untuk mengurangi gema. Pada kenyataannya, menerapkan bangunan yang sepenuhnya kedap suara dianggap kontraproduktif untuk sekolah maupun rumah. Mostafa (2008) mengusulkan akan lebih efektif apabila dilakukan penerapan kontrol akustik yang berbeda-beda disesuaikan dengan jenis kegiatan yang ada di ruangan tersebut.
Spatial Sequencing mensyaratkan bahwa setiap area yang ada di bangunan harus beraturan dan berurutan secara logis. Urutan ruang harus mengalir sehalus mungkin dari aktivitas satu ke aktivitas yang lain, dengan menggunakan sirkulasi satu arah bila memungkinkan. Hal ini bertujuan untuk membuat perilaku para penyandang autis lebih terarah dan membiasakannya terhadap rutinitas.

\section{3.) Escape Space}

Escape Space atau ruang 'pelarian' adalah elemen yang paling mudah untuk diterapkan secara universal pada bangunan. Ruang-ruang pelarian ini memiliki kemampuan dalam menciptakan peluang untuk melepaskan diri dari hal yang sudah mengganggu penyandang autis secara berlebihan, atau kapan pun mereka merasakan kebutuhan untuk 'menyesuaikan kembali'.

\section{4.) Compartmentalisation}

Filosofi di balik kriteria ini adalah untuk mendefinisikan dan membatasi lingkungan sensorik dari setiap kegiatan, mengatur ruang kelas atau bahkan seluruh bangunan menjadi kompartemen. Kualitas sensorik dari setiap ruang harus digunakan untuk mendefinisikan fungsinya dan memisahkannya dari kompartemen sebelahnya. Hal ini akan membantu memberikan isyarat sensorik tentang apa yang diharapkan dari pengguna di setiap ruang.

\section{5.) Transition Space}

Aspek transition space berhubungan dengan aspek spatial sequencing dan sensory zoning. Area transisi ini digunakan untuk membantu menghindari perubahan mendadak dalam fungsi dan stimulasi.

\section{6.) Sensory Zoning}

\section{2.) Spatial Sequencing}


Kriteria ini mengusulkan bahwa ketika merancang untuk autisme, ruang harus diatur dan dikelompokkan sesuai dengan kualitas indra mereka, daripada zonasi fungsional yang khas. Penerapan aspek ini berfungsi untuk mempermudah pemberian penanganan yang tepat dan dapat disesuaikan dengan kebutuhan dari masing-masing kriteria penyandang autis tersebut.

\section{7.) Safety}

Keamanan dan keselamatan adalah suatu hal yang tidak pernah diabaikan ketika mendesain lingkungan untuk anak-anak, keselamatan bahkan lebih menjadi perhatian bagi anak-anak dengan autisme yang mungkin memiliki perasaan yang berubah-ubah terhadap lingkungan mereka misalnya menggunakan perlengkapan keselamatan air panas dan menghindari ujung dan sudut yang tajam.

\section{PEMBAHASAN}

\section{A. Lokasi}

Lokasi perancangan Pusat Pelayanan Autis ini terletak di Jl. Guntung Manggis, Kecamatan Landasan Ulin, Kota Banjarbaru. Titik koordinat: $3^{\circ} 27^{\prime} 35.2^{\prime \prime} \mathrm{S}+114^{\circ} 47^{\prime} 38.3^{\prime \prime} \mathrm{E}$. Luasan tapak yang diambil adalah $6.173 \mathrm{~m} 2$.

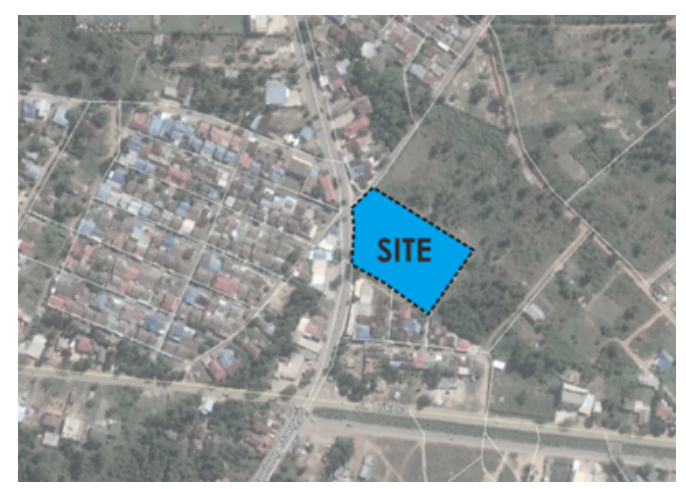

Gambar 6. Lokasi Tapak

Sumber: Data Pribadi (2020)

Lokasi perancangan yang dipilih berada di Banjarbaru karena menyesuaikan dengan data jumlah anak autis di Kalimantan Selatan yang terbanyak adalah di Banjarbaru, sehingga tingkat urgensi kepentingan Pusat Pelayanan Autis ini lebih diutamakan di Banjarbaru. Pertimbangan pemilihan tapak di Jl. Guntung Manggis dipilih berdasarkan beberapa kelebihan yang ada di sekitarnya yaitu:

- Dekat dengan kantor Bina Autis Indonesia dan RSUD Idaman Banjarbaru ( \pm $1 \mathrm{~km}$ dari site)

Tapak tidak berada di pusat kota sehingga kepadatan kendaraan yang berlalu lalang di sekitar Jalan Guntung Manggis ini relatif sedang, hal ini memberikan dampak positif dalam segi keamanan;

Kepadatan penduduk di sekitar tapak relatif sedang, hal ini juga memberikan dampak positif dalam segi keamanan dan segi sosial;

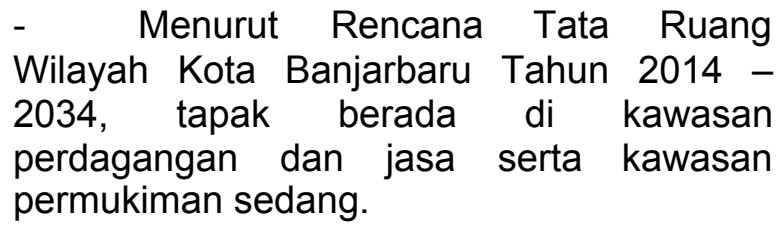

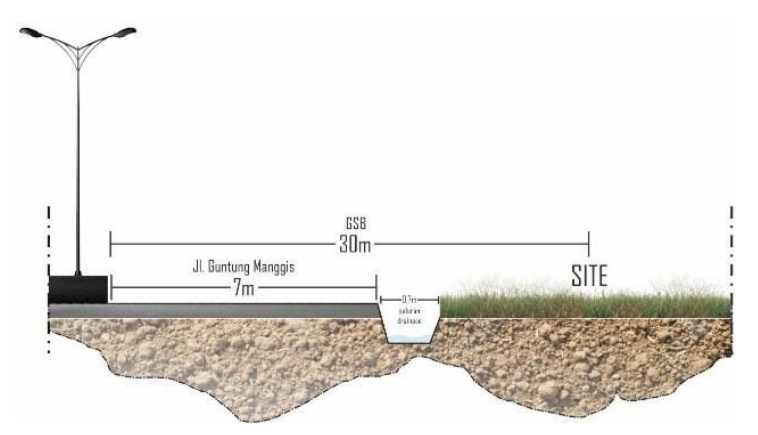

Gambar 7. Potongan Tapak Sumber: Data Pribadi (2020)

\section{B. Konsep Rancangan}

1. Konsep Program

Berdasarkan permasalahan dari Pusat Pelayanan Autis di Banjarbaru yaitu bagaimana rancangan Pusat Pelayanan Autis di Banjarbaru yang mampu menciptakan ruang yang baik dan tepat untuk mendukung kegiatan pengembangan diri para penyandang autis, maka diterapkanlah ketujuh prinsip 'The Autism ASPECTSS Design Index' sebagai 
parameter rancangan untuk menjawab permasalahan tersebut.

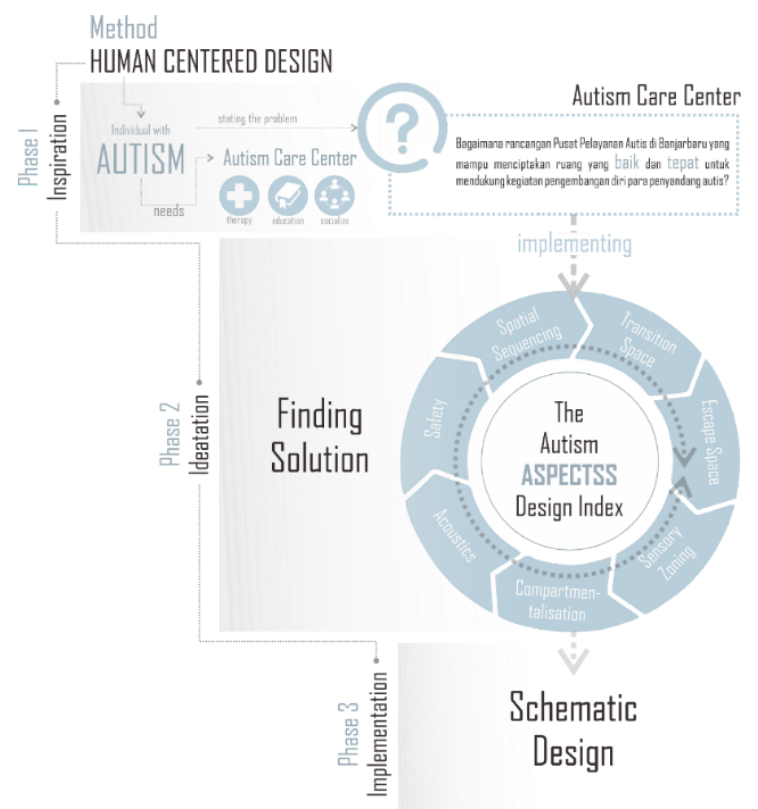

Gambar 8. Diagram Konsep Programatik Sumber: Analisis Pribadi (2020)

\section{Penerapan Prinsip The Autism ASPECTSS Design Index}

\section{- Compartmentalisation}

Penerapan aspek compartmentalisation pada perancangan Pusat Pelayanan Autis ini adalah berupa pembagian massa bangunan yang dibagi sesuai dengan fungsi dan kegiatan masing-masing agar setiap kegiatan dapat di kompartemen kan dan difokuskan pada masing-masing bangunan.

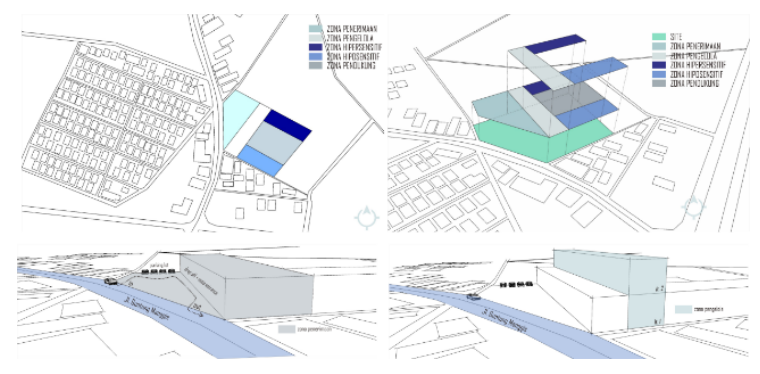

Gambar 9. Pembagian Zonasi pada Tapak Sumber: Analisis Pribadi (2020)

\section{- Sensory Zoning}

Penerapan aspek sensory zoning pada perancangan Pusat Pelayanan Autis ini adalah berupa pembagian zonasi yang dikelompokkan berdasarkan kriteria atau karakter penyandang autis yaitu dari segi stimulasi sensorinya (hiposensitif dan hipersensitif), dan pemenuhan kebutuhan para penyandang autis yang disesuaikan dengan kemampuan sensorisnya.

\section{- Zona Hipersensitif}

Penyandang autis dalam klasifikasi hipersensitif memiliki tingkat kepekaan yang berlebih terhadap stimulasi sensoris. Ditinjau dari karakter penyandang autis tersebut maka ruang yang ada pada zona hipersensitif menggunakan elemen-elemen rancangan yang mampu untuk meredam dan menstabilkan kepekaan sensoris yang berlebih pada para penyandang autis hipersensitif tersebut. Zona hipersensitif menggunakan warna-warna pastel yang termasuk ke dalam kategori cool color untuk memberikan ketenangan dan meredam stimulasi sensoris terutama indera 87 penglihatan para penyandang autis hipersensitif. Menghindari penggunaan material bertekstur kasar dan memperbanyak tekstur-tekstur yang bersifat lunak dan halus. Langit-langit atau plafon dibuat rendah yaitu 3 - 3,5 meter dari permukaan lantai untuk meminimalisir intensitas gema yang dihasilkan dan untuk membuat para penyandang autis agar tidak merasa tercekam.

Zona hiposensitif berorientasi ke arah dalam agar para penyandang autis lebih berfokus kepada kegiatan yang sedang dilakukan. Menggunakan material solid dan bukaan yang tidak terlalu lebar pada dinding untuk meminimalisir distraksi dari luar mengingat karakter dari penyandang autis terutama klasifikasi hipersensitif adalah mudah kehilangan fokus. Sirkulasi penghawaan menggunakan sistem cross ventilation atau bukaan yang terdapat pada dua sisi yang berseberangan agar udara yang berada di dalam ruangan dapat mudah berganti dengan udara yang lebih segar sehingga tidak membuat ruangan menjadi pengap dan bau 
mengingat para penyandang autis pada klasifikasi hipersensitif sangat peka terhadap penciuman.

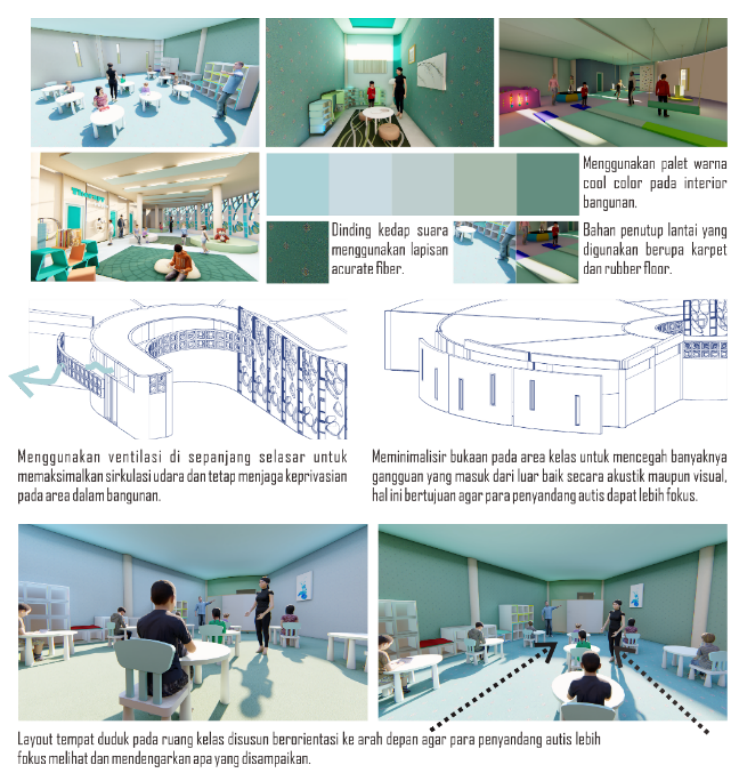

Gambar 10. Konsep Zona Hipersensitif Sumber: Analisis Pribadi (2020)

- Zona Hiposensitif

Penyandang autis dalam klasifikasi hiposensitif memiliki tingkat kesensitifan yang rendah terhadap stimulasi sensoris. Ditinjau dari karakter penyandang autis tersebut maka ruang yang ada pada zona hiposensitif menggunakan elemen-elemen rancangan yang mampu untuk mengasah dan meningkatkan kepekaan sensoris para penyandang autis hiposensitif tersebut. Secara garis besar, ruangan-ruangan yang terdapat pada zona hiposensitif dibuat dengan konsep terbuka dan luas. Zona hiposensitif dibuat dengan langit-langit yang tinggi dan space yang luas agar menghasilkan intensitas gema yang tinggi untuk mengasah stimulasi pendengaran penyandang autis hiposensitif.

Warna-warna yang digunakan pada zona hiposensitif adalah warna-warna cerah yang termasuk dalam kategori warm color untuk menarik perhatian dan mengasah stimulasi visual para penyandang autis hiposensitif. Penggunaan material bertekstur kasar namun masih dalam batas aman juga diterapkan untuk mengasah indera peraba atau taktil. Zona hiposensitif berorientasi ke arah view eksternal berupa Ruang Terbuka untuk menciptakan daya tarik bagi penggunanya. Pada dinding yang mengarah ke ruang terbuka menggunakan material kaca untuk memaksimalkan view dari dalam ke luar maupun sebaliknya. Sirkulasi penghawaan menggunakan sistem closed ventilation atau bukaan yang hanya terdapat pada satu sisi yang diletakkan pada bagian yang paling dekat dengan ruang terbuka. Disekitar area bukaan diberi vegetasi berupa tanaman yang mengandung wewangian (aromatherapy) agar terbawa oleh angin yang masuk sehingga dapat menstimulasi indera penciuman para penyandang autis hiposensitif.
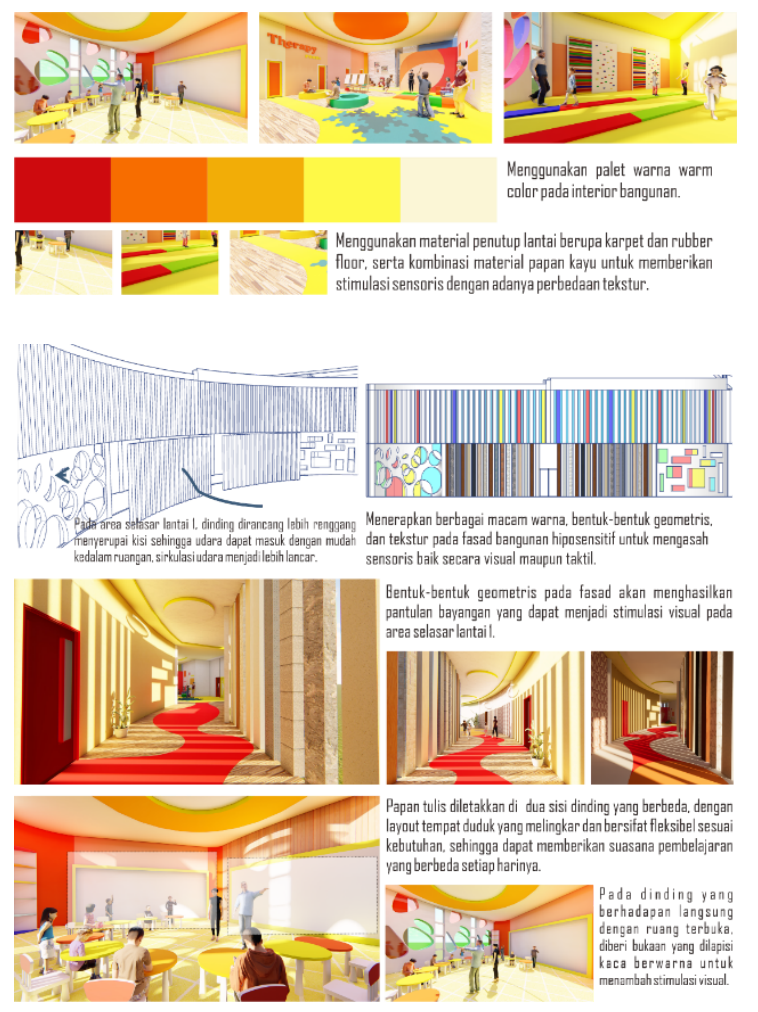

Gambar 11. Konsep Zona Hiposensitif Sumber: Analisis Pribadi (2020)

\section{- Spatial Sequencing}

Penerapan aspek spatial sequencing pada perancangan Pusat Pelayanan Autis ini adalah berupa sirkulasi dan perletakan zonasi yang disesuaikan dengan pola aktivitas pengguna terutama para penyandang autis. Hal ini dilakukan untuk 
menciptakan dan mengajarkan rutinitas kepada para penyandang autis tersebut.

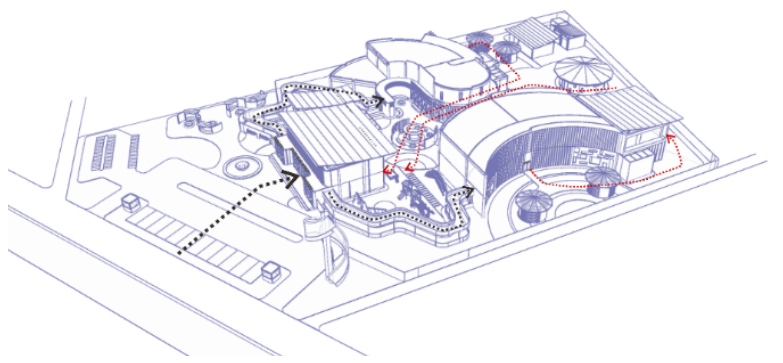

Gambar 12. Arah Sirkulasi

- Transition Space

Sumber: Analisis Pribadi (2020)

Penerapan aspek transition space pada perancangan Pusat Pelayanan Autis ini adalah berupa sebuah Ruang Terbuka dengan konsep taman interaktif yang berada di tengah-tengah tapak. Selain menjadi area untuk bersosialisasi, ruang terbuka ini juga dijadikan sebagai area transisi dari kedua zona stimulasi sensoris hiposensitif dan hipersensitif.

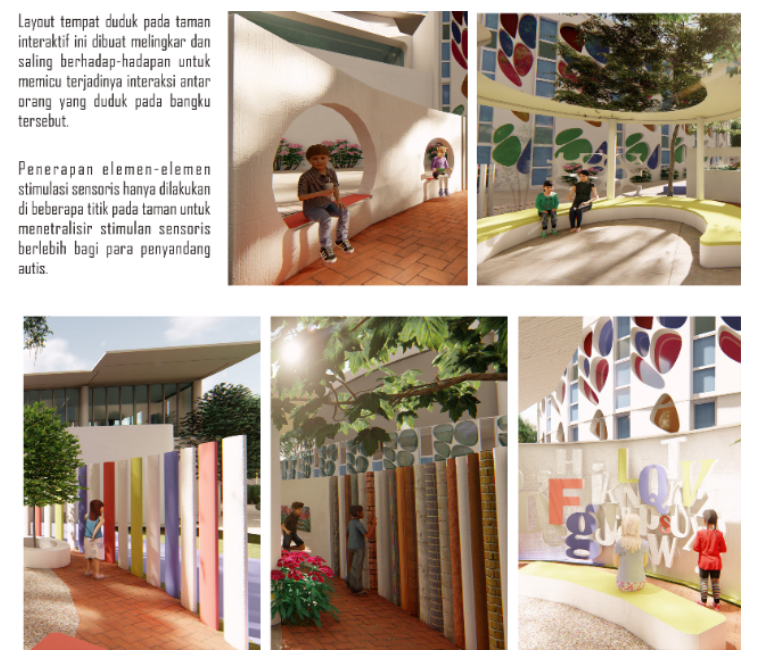

Gambar 13. Konsep Taman

Sumber: Analisis Pribadi (2020)

\section{- Escape Space}

Penerapan aspek escape space pada perancangan Pusat Pelayanan Autis ini adalah berupa ruang relaksasi yang diletakkan di beberapa titik pada tapak. Fungsi dari ruang relaksasi tersebut adalah untuk para penyandang autis menenangkan diri saat mereka mulai merasa lelah dan risih terhadap stimulasi-stimulasi sensoris yang didapatkan pada zona hipersensitif maupun zona hiposensitif.

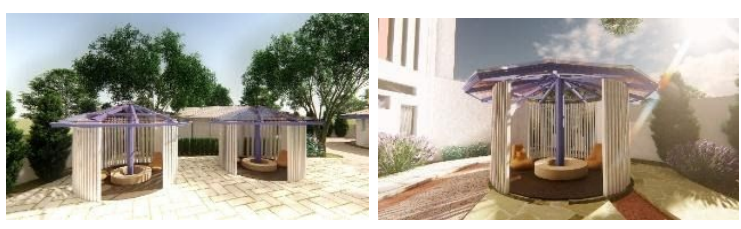

Gambar 14. Ruang Relaksasi

Sumber: Analisis Pribadi (2020)

\section{- Acoustics}

Penerapan aspek akustik pada perancangan Pusat Pelayanan Autis ini adalah berupa pemberian material peredam suara pada ruangan yang anti distraksi terutama pada zona hipersensitif, penerapan langit-langit yang tinggi pada ruangan yang membutuhkan stimulasi auditori, terutama pada zona hiposensitif, untuk menciptakan intensitas gema yang tinggi, dan penerapan langit-langit yang rendah pada ruangan yang membutuhkan ketenangan, terutama pada zona hipersensitif, untuk meredam gema.

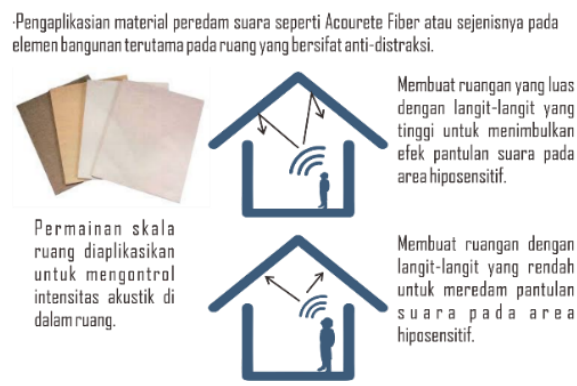

Gambar 15. Kontrol Akustik Sumber: Analisis Pribadi (2020)

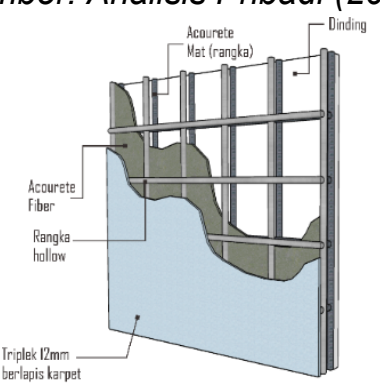

Gambar 16. Dinding Acourete Fiber Sumber: Analisis Pribadi (2020)

\section{- Safety}


Penerapan aspek safety pada perancangan Pusat Pelayanan Autis ini adalah berupa penggunaan busa pelindung pada setiap sudut tajam, dan adanya pagar pembatas di sekeliling tapak.

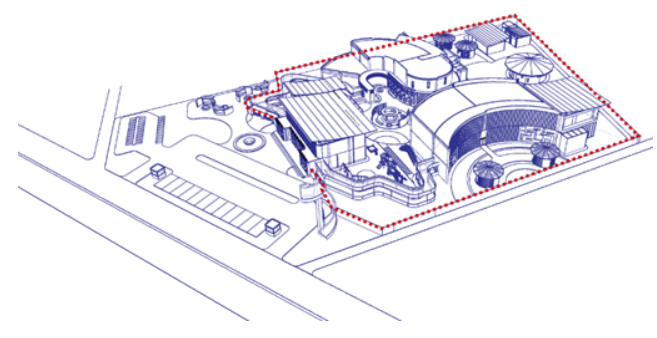

Gambar 17. Pagar Pembatas Sumber: Analisis Pribadi (2020)

HASIL

- Siteplan

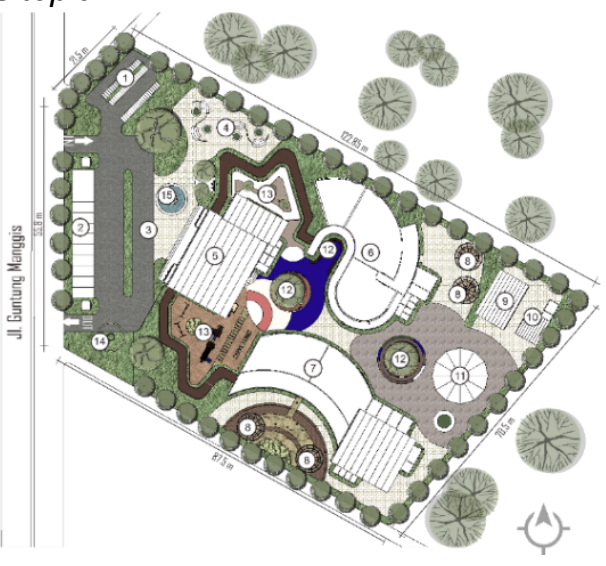

Gambar 18. Rencana Tapak Sumber: Analisis Pribadi (2020)

- Tampak Kawasan

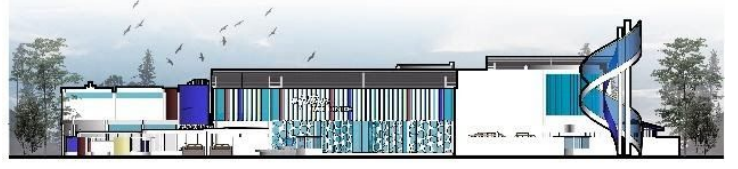

Gambar 18. Tampak Depan Kawasan Sumber: Analisis Pribadi (2020)

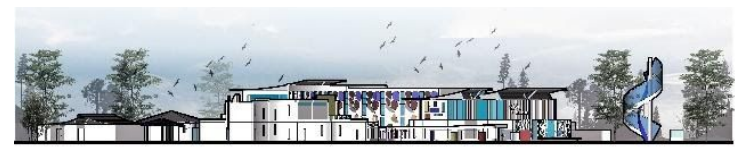

Gambar 19. Tampak Samping Kiri Kawasan
Sumber: Analisis Pribadi (2020)

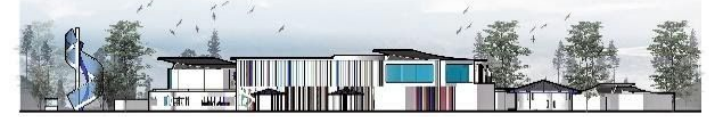

Gambar 20. Tampak Samping Kanan Kawasan Sumber: Analisis Pribadi (2020)

- Perspektif Eksterior

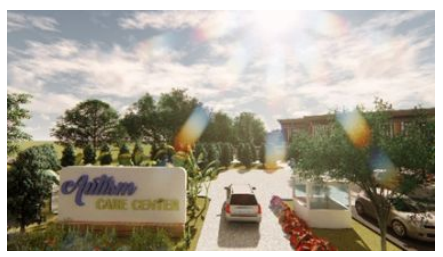

Gambar 21. Signage

Sumber: Analisis Pribadi (2020)

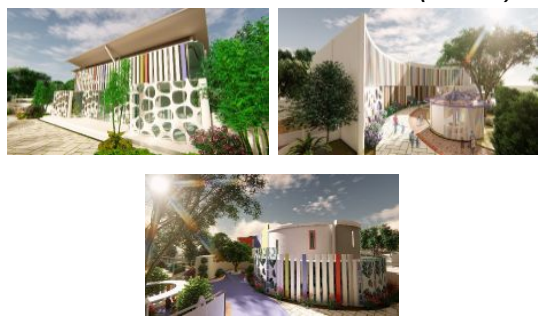

Gambar 22. Eksterior Bangunan Sumber: Analisis Pribadi (2020)

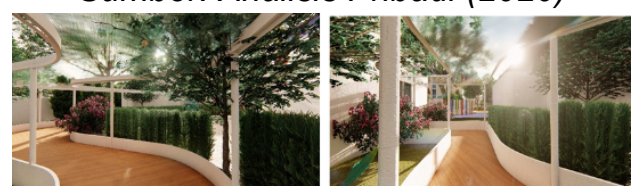

Gambar 23. Selasar Terbuka Sumber: Analisis Pribadi (2020)

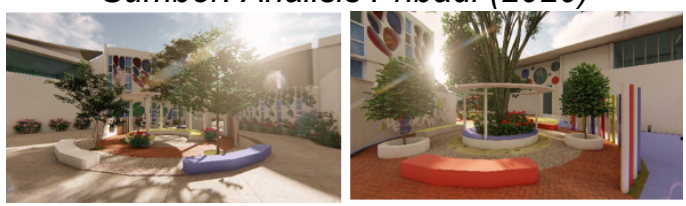

Gambar 24. Modul Taman

Sumber: Analisis Pribadi (2020)

- Perspektif Interior

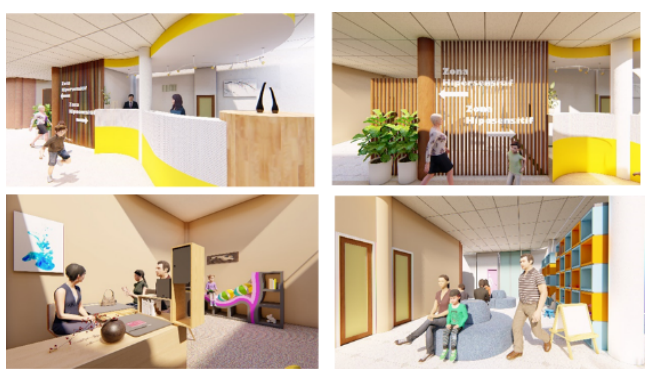

Gambar 25. Interior Zona Penerimaan Sumber: Analisis Pribadi (2020) 


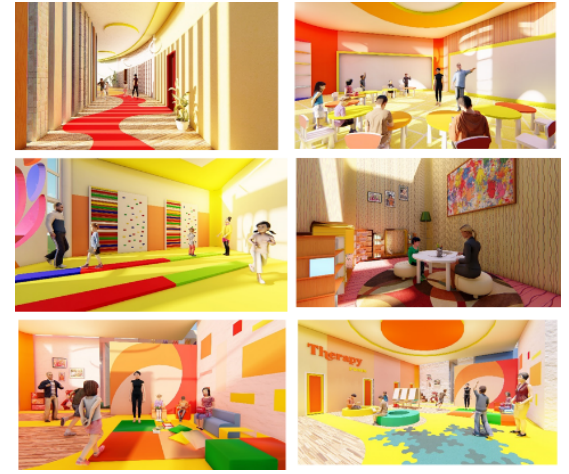

Gambar 26. Interior Zona Hiposensitif Sumber: Analisis Pribadi (2020)

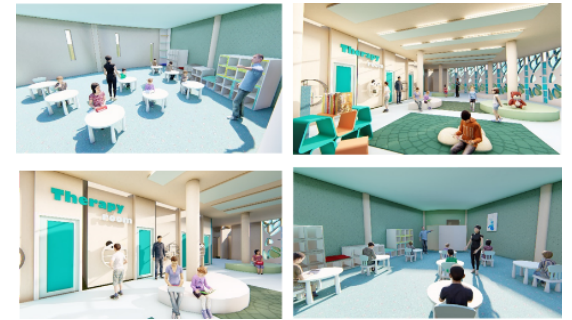

Gambar 27. Interior Zona Hipersensitif Sumber: Analisis Pribadi (2020)

\section{KESIMPULAN}

Perancangan Pusat Pelayanan Autis di Banjarbaru ini merupakan sebuah upaya menciptakan ruang yang baik dan tepat untuk mendukung kegiatan pengembangan diri para penyandang autis. Penyelesaian masalah pada Pusat Pelayanan Autis di Banjarbaru ini berfokus kepada bagaimana cara memberikan fasilitas pelayanan yang sesuai dengan kebutuhan karakter masing-masing penyandang autis untuk mengembangkan diri. Fasilitas pelayanan yang diberikan yaitu berupa fasilitas pendidikan, fasilitas terapi, dan fasilitas sosial. Bentuk pelayanan pada Pusat Pelayanan Autis tersebut diimbangi dengan elemen-elemen rancangan yang juga menyesuaikan dengan kebutuhan dan karakter masing-masing penyandang autis.

Metode Human Centered Design (HCD) dipilih sebagai metode untuk mencari solusi dari permasalahan pada rancangan Pusat Pelayanan Autis di Banjarbaru. Metode Human Centered Design dianggap mampu untuk menemukan solusi dari permasalahan rancangan ini karena merupakan metode yang berfokus untuk memberikan kehidupan yang lebih baik bagi penggunanya. Melalui tahapan-tahapan dari metode HCD, konsep penerapan prinsip The Autism ASPECTSS Design Index didapat setelah melakukan proses studi literatur dan analisis. Penerapan konsep ini sebagai parameter rancangan dianggap mampu menjawab permasalahan secara arsitektural dan mencapai tujuan dari rancangan Pusat Pelayanan Autis di Banjarbaru.

\section{DAFTAR PUSTAKA}

\section{Referensi Buku dan Jurnal}

American Psychiatric Association. (2013). Diagnostic and Statistical Manual of Mental Disorders - V Edition. Arlington, VA.

Faisal Y. (2003). Autisme: Suatu Gangguan Jiwa pada Anak-anak. Jakarta: Pustaka Popular Obor.

Mostafa, Magda. (2008). An Architecture for Autism: Concepts of Design Intervention for the Autistic User. Archnet-IJAR : International Journal of Architectural Research.

2. 10.26687/archnet-ijar.v2i1.182.

Yuwono, J. (2009). Memahami Anak Autistik. Bandung: CV Alfabeta.

\section{Website}

Astuti, Anggi D. (2018). Penerapan Warna Pada Ruang Interior Anak Autis. Narada, vol. 5, pp. 35-46. Diambil kembali dari https://publikasi.mercubuana.ac.id/index.p hp/narada/article/view/4063

Coates, G.J. (2000). Seven Principles of Life-Enhancing Design ; The Architecture of Erik Asmussen. Stockholm: Design \& Health World Congress \& Exhibition. Diambil kembali dari BRIK https://www.brikbase.org/sites/default/files/ 44GaryCoates-WCDH2000.pdf

Frechmann. (2014). 500 trick. Color. Diambil kembali dari http://iptek.its.ac.id/index.php/jdi/article/vie $w / 1461$

Veskariyanti, A.G. (2008). 12 Terapi Autis Paling Efektif \& Hemat: untuk Autisme, Hiperaktif, dan Retardasi Mental. Yogyakarta: Percetakan Galangpress. Diambil kembali dari UIN Malang 
http://etheses.uin-malang.ac.id/2273/6/084

10062_Bab_2.pdf 